\title{
Collapsing (New) Buildings: Town Planning, History and Music in Hubertus Siegert's Berlin Babylon (2001)
}

\author{
Andrew W. Hurley, University of Technology Sydney
}

\section{Introduction}

Hubertus Siegert's impressionistic documentary, Berlin Babylon, illuminates the demolition and urban renewal of Berlin during the mid to late 1990s. This was a critical phase in the city's history, as it prepared, amidst a flurry of excitement and anticipation, to become the united Germany's seat of power. Siegert's film seeks to give pause for thought, but deliberately eschews a 'voice of god' voiceover, opting instead for a poetic audiovisual montage. This includes shots of the cityscape (and its lacunae), archival footage documenting the wartime devastation and subsequent dynamiting of buildings, observational cinema of the city's busy building sites, and of verbal snippets from various architects, developers and politicians—following the film title's cue, the agents in a rerun of the construction of the Tower of Babel—as well as epigraphs from the Bible and Walter Benjamin, and a prominent soundscape and musical score. As this article demonstrates, the film's (mostly) sombre soundtrack plays a critical role here, commenting on the footage, and, beyond that, on the whole project of the new 'Berlin Republic' and its attitude to architectural heritage and twentieth century history. Refiguring the theme of this special issue of PORTAL, Berlin Babylon's music is a form of writing about (collapsing, old) architecture and history. And yet, the soundtrack is not as unambiguous as a voiceover might have been, and thereby allows creative space for the audience's interpretation, a matter that was very important to the film's director. This article focuses, in particular, on three elements: the use (and treatment) of historical recordings in the film; the use of silence; and finally the way in which tracks from the 
Berlin band, Einstürzende Neubauten, use music, noise and text to comment on the project of the new Berlin.

\section{Berlin before and after the wall}

Among Europe's capitals, Berlin had a tumultuous $20^{\text {th }}$ century history, to say the least. Physically, it was severely damaged during the course of the Second World War; indeed only ten percent of the capital's buildings survived unscathed (Siegert and Stern 2002). For numerous reasons, the city would not be rebuilt according to its pre-war design. Many ruins were in a precarious state and safety, combined with a lack of funds to allow for restoration, dictated their demolition. Ideological concerns compounded certain decisions, such as the demolition in 1950 of the eighteenth century Stadtschloss (figure 1), the ruins of which occupied an important site in the heart of East Berlin, capital of the then recently founded German Democratic Republic. Besides the exorbitant cost involved in renovation-East and West Germany were both states under economic construction - the Stadtschloss was associated with the old Prussian state and was therefore thought not entirely worthy of the new socialist state (Colomb 2007). Far more appropriate was a project like the Karl-Marx-Allee (East Berlin’s main East-West thoroughfare), which was initially conceived as a $70^{\text {th }}$ birthday present for Joseph Stalin (figure 2).

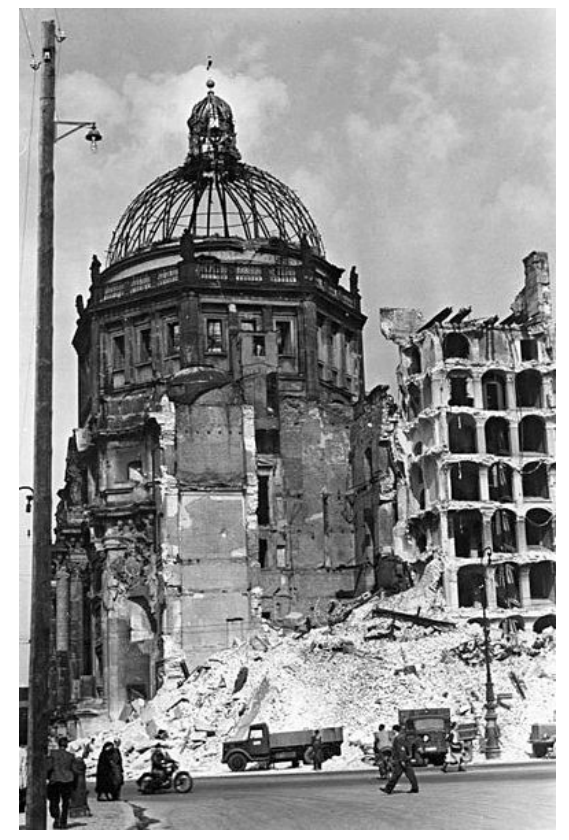

Figure 1. The Stadtschloss during demolition, 1950. Photographer: unknown. Image courtesy of the Deutsches Bundesarchiv (Bundesarchiv Bild 183-07964-0001; Creative Commons CC-BY-SA 3.0). 


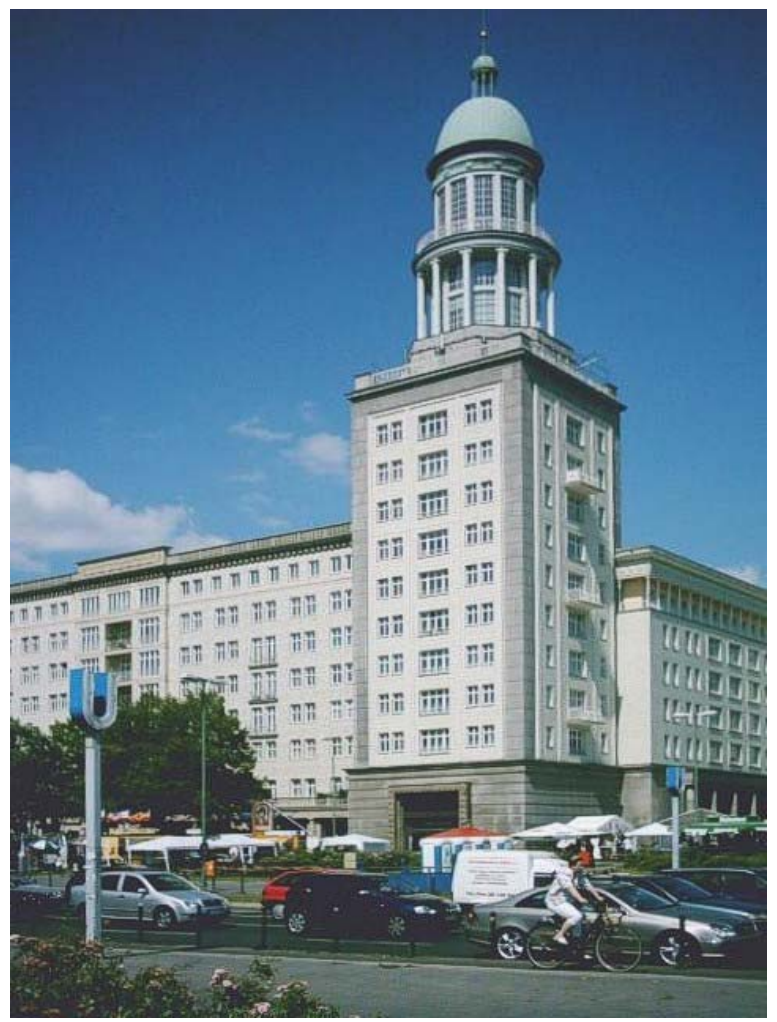

Figure 2. The Frankfurter Tor, Karl-Marx-Allee (http://upload.wikimedia.org/wikipedia/de/5/5a/Pic00716.jpg). Public domain.

Not all of East Berlin's buildings were designed in this grand style, however. Rather, a far plainer DDR Moderne (GDR modernism) or 'Soviet version of modernism’ (Neill 2005: 338) came to hold sway. During the 1960s and 1970s, in particular, demolitionwhat Ralph Stern calls ‘urban erasure’ (2002: 128)—continued apace, as older buildings were demolished and modernist buildings, including many Plattenbauten (prefabricated high rise constructions), were erected in their place (figure 3). These buildings were far cheaper than a restoration of the buildings they replaced, and also offered modern amenities. The division of the city, consummated by the building of the Berlin Wall in August 1961, contributed to the urban scarification, particularly of the inner city, which now accommodated both the Wall and, on the Eastern side, a sizeable 'death strip' or buffer zone patrolled by dogs and armed guards ordered to shoot any East German citizens who might try to escape.

This is not to say that West Berlin was in a completely different situation. It too faced housing problems, and there was considerable redevelopment in the West, again in a modernist style. However, this did not hold for all of West Berlin. The Kaiser-Wilhelm- 


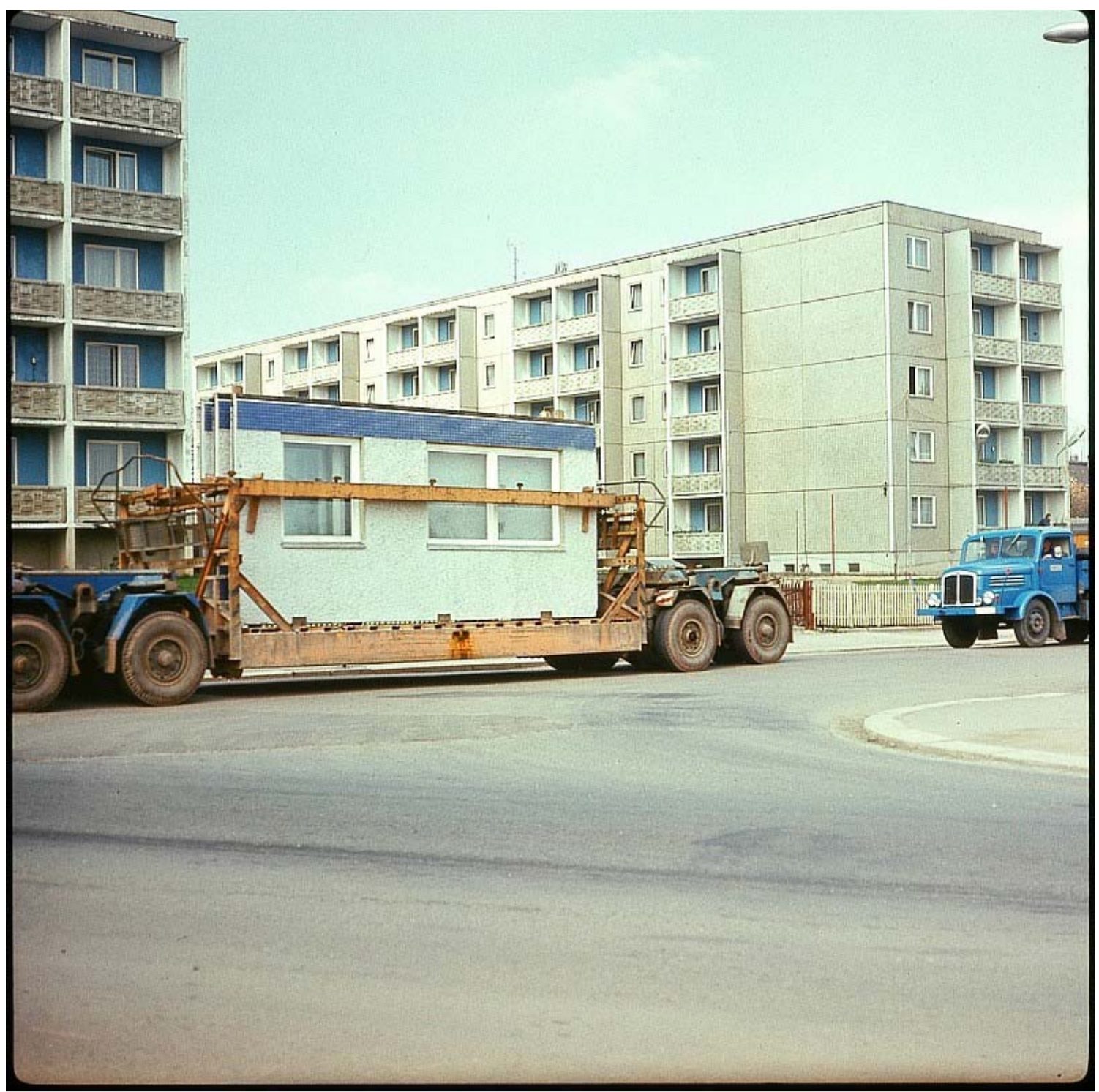

Quelle: Deutsche Fotothek

Figure 3. Plattenbau under construction in Chemnitz (Karl-Marx-Stadt), 1975.

Photographer: Eugen Nosko. Image courtesy of the Deutsche Fotothek (Fotothek Bild df n-07 0000047).

Gedächtniskirche, which occupies a special place on the Kurfürstendamm, West

Berlin's main street, had been severely damaged in the War; it was the subject of a

'renovation' which made a feature of its bombed state (figure 4). On the other hand, the inner city suburb of Kreuzberg, located close by the Wall, was allowed to decay. It became home in the 1970s to both a large contingent of Turkish work migrants, and to students, artists, squatters and anarchists, who took advantage of the low rents, or squatted in abandoned buildings (figure 5). 


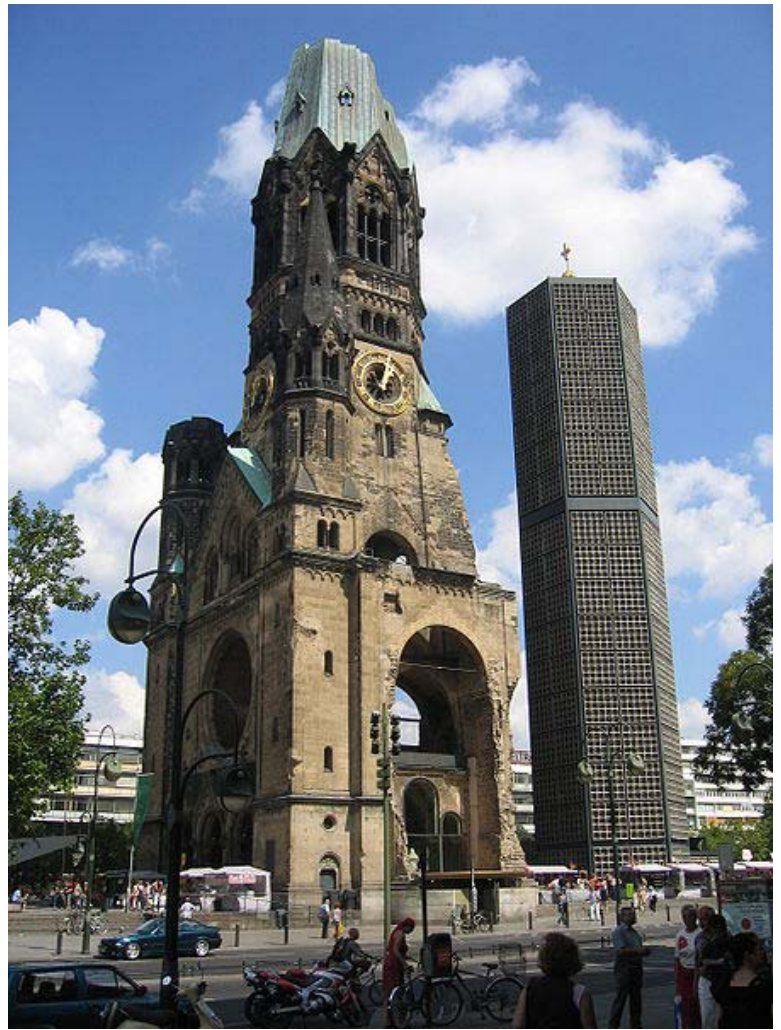

Figure 4: Kaiser-Wilhelm-Gedaechtnis-Kirche.

(http://de.wikipedia.org/w/index.php?title=Datei:Ged\%C3\%A4chtniskirche1.JPG\&filetimestamp=20051 112144939). Public domain.

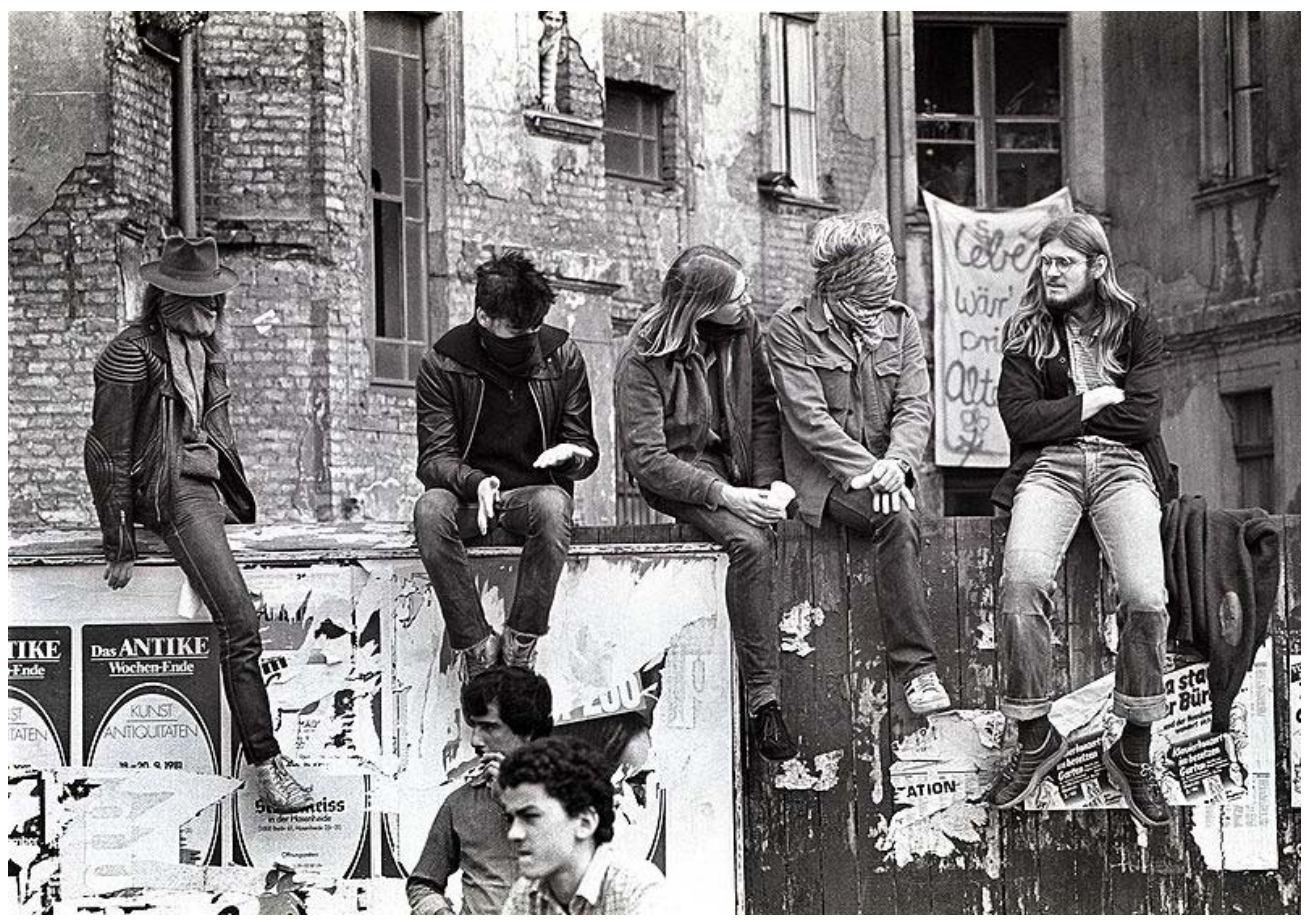

Figure 5. Squatters in Berlin, Kreuzberg (1981). Photo: Tom Ordelmann

(http://de.wikipedia.org/wiki/Datei:Instandbesetzer_Berlin_Kreuzberg_1981.jpg). Creative Commons. 
The rather unexpected fall of the Wall in November 1989, and the rushed unification of Germany the following year, threw up all sorts of issues that would have seemed unthinkable only a short while before. In particular, there was the question of the status of Berlin - the capital of Germany up until 1945, and until 1990, the (former) East German capital and rival to the West German state’s seat of power, Bonn, an unassuming city far removed from the Cold War's frontline and the ghosts of the German past. In retrospect, the decision to move the seat of power back to Berlin seems inevitable, yet it was a close decision when put to a Bundestag vote in 1991. That move, which took place between 1998 and 2000, was momentous for the city’s built environment. As David Clay Large noted in 2001: 'No other city in modern times has witnessed such a far-reaching overhaul in so short a time. But Berlin's makeover was unique in spirit as well as in scale; ... the task presented a singular complex of political, psychological, and moral dilemmas' (586). Two competing processes were at work here, as Claire Colomb identifies: 'the politics of collective memory and identity (re)construction through architecture and planning ... [and] the renegotiation of the social uses and public nature of ... strategic inner-city site[s] in a market economy’ (2007: 283). Central to the former, and to the debates about the appropriate form of urban renewal were two ways of approaching the capital's history. Was Berlin a 'city that "is always becoming and never is" ... [or one] that "already exists and need not be discovered anew”' (Large 2001: 586). ${ }^{1}$ These questions of rupture and flux versus continuity and restoration resonated also with fundamental questions of German historiography. How ought one to view the Nazi period and authoritarian rule in the GDR: as a central part of the fabric of Germany, or as an exceptional phase, somehow counter to a more respectable broader trajectory of German history? This matter had been in mainstream circulation at least since the mid-1980s and the so-called Historikerstreit (historians' debate). ${ }^{2}$ However, the problematic question of a 'return' to German 'normalcy’ was necessarily thrown up again by the unification of Germany, and especially by the return to Berlin—if one were inclined to listen. Svetlana Boym notes that, in this context, reflective moral discourse was 'on the verge of disappearing in the hectic pace of development' (quoted in Ledanff 2003: 49).

\footnotetext{
${ }^{1}$ Large is quoting Die Zeit.

${ }^{2}$ The term Historikerstreit signifies the divisive debate between conservative historians and politicians who made 'historicizing' comparisons between the Holocaust and other acts of genocide, and those leftists who refused to do so, maintaining that Germany was a scar that should not be able to heal. On the Historikerstreit, see, for example, Augstein et al (1987).
} 


\section{'Critical reconstruction,' two central sites, and a void?}

Hans Stimmann, the City of Berlin’s building commissioner between 1991 and 1996and a figure who appears several times in Hubertus Siegert's film Berlin Babylon (2001a) - represented a restorationist tendency in the debate (figure 6). He championed a planning scheme that sought to plug the gaps in the cityscape, and gave precedence to a 'classical modern' aesthetic — a 'mix of Karl Friedrich Schinkel's classicism and Peter Behren's once daring modernism, with Heinrich Tessenow as modernist thrown in to secure an anti-avant-gardist and anti-Weimar politics of traditionalism,' as Andreas Huyssen puts it (1997: 67-68). By 1995, Stimmann’s policy of 'critical’ or 'historical reconstruction' had been settled, and marked a definite 'aesthetic turn' (Ledanff 2003: 56). Stimmann's policy had its critics as well. These included Daniel Libeskind, the Polish-born Jewish architect who was responsible for the design of the city's Jewish Museum, which also features in Siegert's film (see below). Libeskind accused Stimmann of nostalgia, of ignoring an alternative history of innovative architecture, and of 'the total erasure of fifty years of history of this city. It is going back to a time when

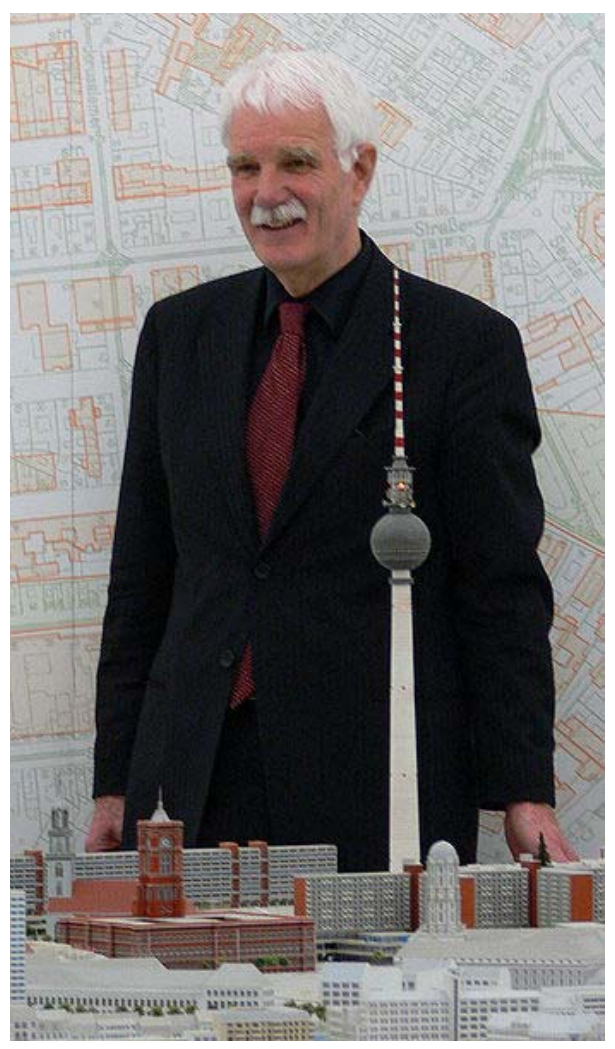

Figure 6. Hans Stimmann, 2006. Photo: Hans Praefcke (http://de.wikipedia.org/w/index.php?title=Datei:Hans_Stimmann.jpg\&filetimestamp=20070521081753). Public domain. 
things were not problematic, coupled with an authoritarian ideal of how to develop the city' (quoted in Large 2001: 588-589).

Descending briefly from the abstract to the particular, several important sites that are depicted in Siegert's film ought to be introduced. The Potsdamer Platz, which had been an important hub prior to its destruction in the Second World War, had, given its proximity to the border, become fallow land, a sort of 'city prairie.' In the eyes of the city's fathers, it was a particular 'void' needing to be filled, though, as Andreas Huyssen notes, it was a 'void filled with history and memory' (1997: 75). Its development was decided upon very early in the 1990s; and the land was sold off to a number of corporations (including Daimler-Chrysler and Sony) that engaged various worldrenowned architects (including Renzo Piano, Helmut Jahn and others) to design their German headquarters (figure 7). For Stuart Taberner, the slick yet bland Potsdamer

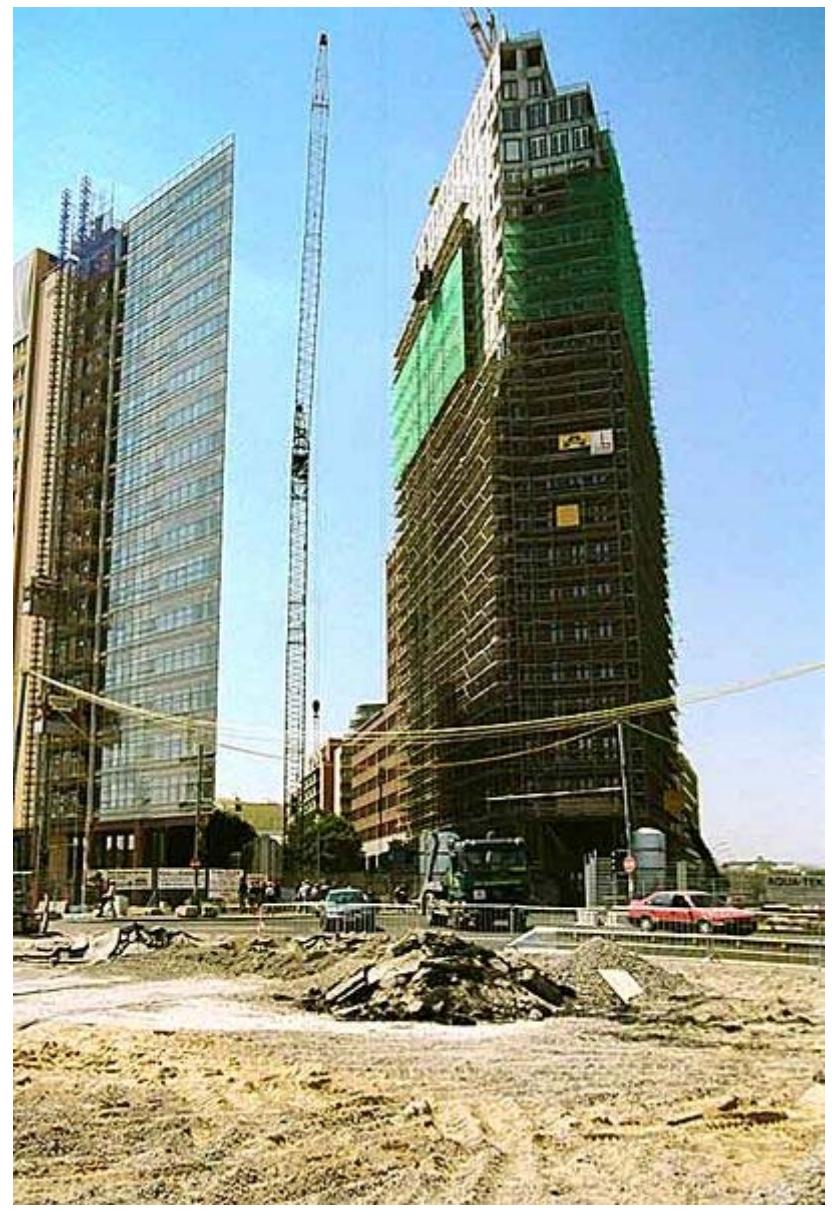

Figure 7. The Kolhoff tower under construction, Potsdamer Platz, 1999. Photo: Roger Koslowski (http://de.wikipedia.org/w/index.php?title=Datei:Potsdamerplatz5.jpg\&filetimestamp=20060712213306). Creative Commons. 
Platz redevelopment represents what he calls a trend in the Berlin Republic towards a global, 'ahistorical normality.' It alludes vaguely to the architecture of the 1920s, but it does so in a way that is largely stripped of any historical specificity (Taberner 2005: xviii). Hence, the redevelopment of the Potsdamer Platz threw into relief a conflict between the historical city of Berlin and a new thrust towards global consumerism, as represented by Sony and the other firms that set up shop there (Ledanff 2003: 49).

The Schlossplatz, which had been a focal point of the old centre of the city (and was an important site in the East German capital), was a far trickier matter. It was, to use Strom’s coinage, a heavily ‘burdened landscape’ (quoted in Colomb 2007: 284). Formerly the site of the old Stadtschloss, it had, since the mid-1970s, accommodated the so-called Palast der Republik (Palace of the Republic), which housed the Volkskammer (Peoples' Chamber) and other amenities, including an entertainment complex (figure 8). This DDR Moderne building was - in the eyes of its detractors-both ugly and tainted. It was also riddled with asbestos. And yet the demolition of the building, which was decided upon in 1993 (but subjected to a stay in 1994), and then finally commenced only in 2006-2007, was not unproblematic. ${ }^{3}$ It seemed to ride roughshod over the sentiments of many East Berliners, including those who had fond memories of the building, or who otherwise resented the cavalier attitude of the new West-German masters. It also raised uncomfortable questions about what to construct in its stead: a new building or a reconstruction of the Stadtschloss? ${ }^{4}$ Would this be revanchist, and/or a 'falsification of history' (Colomb 2007: 298)? The site seemed to focus 'rival nostalgias': one 'ostalgic'; the other yearning for a period prior to the $20^{\text {th }}$ century, and its ruinous history and architectural modernism (Large 2001: 600). Yet attitudes did not necessarily cleave along East/West lines. (Ledanff 2003: 40; Colomb 2007: 302). This site also stood as a cipher for the issue of how, if at all, to accommodate 'uglier' parts of Berlin's and Germany's recent history. And, of course, that history extended beyond the relatively short life of the GDR.

\footnotetext{
${ }^{3}$ On the steps leading to the demolition, see Colomb (2007).

${ }^{4}$ This was the decision ultimately voted through by the Bundestag in 2002, after a report presented by an international Commission of Experts (Kommission Historische Mitte Berlin) under the leadership of the Austrian politician Hannes Swoboda.

${ }^{5}$ On the many iterations of Ostalgie, that is, nostalgia for the former East Germany, see Cooke (2005). This is not to say that Ostalgie alone explains the palette of East German sentiment against the demolition of the Palast. Many East Berliners had good reason to resent the way in which their country seemed to have been simply taken over by West Germany.
} 


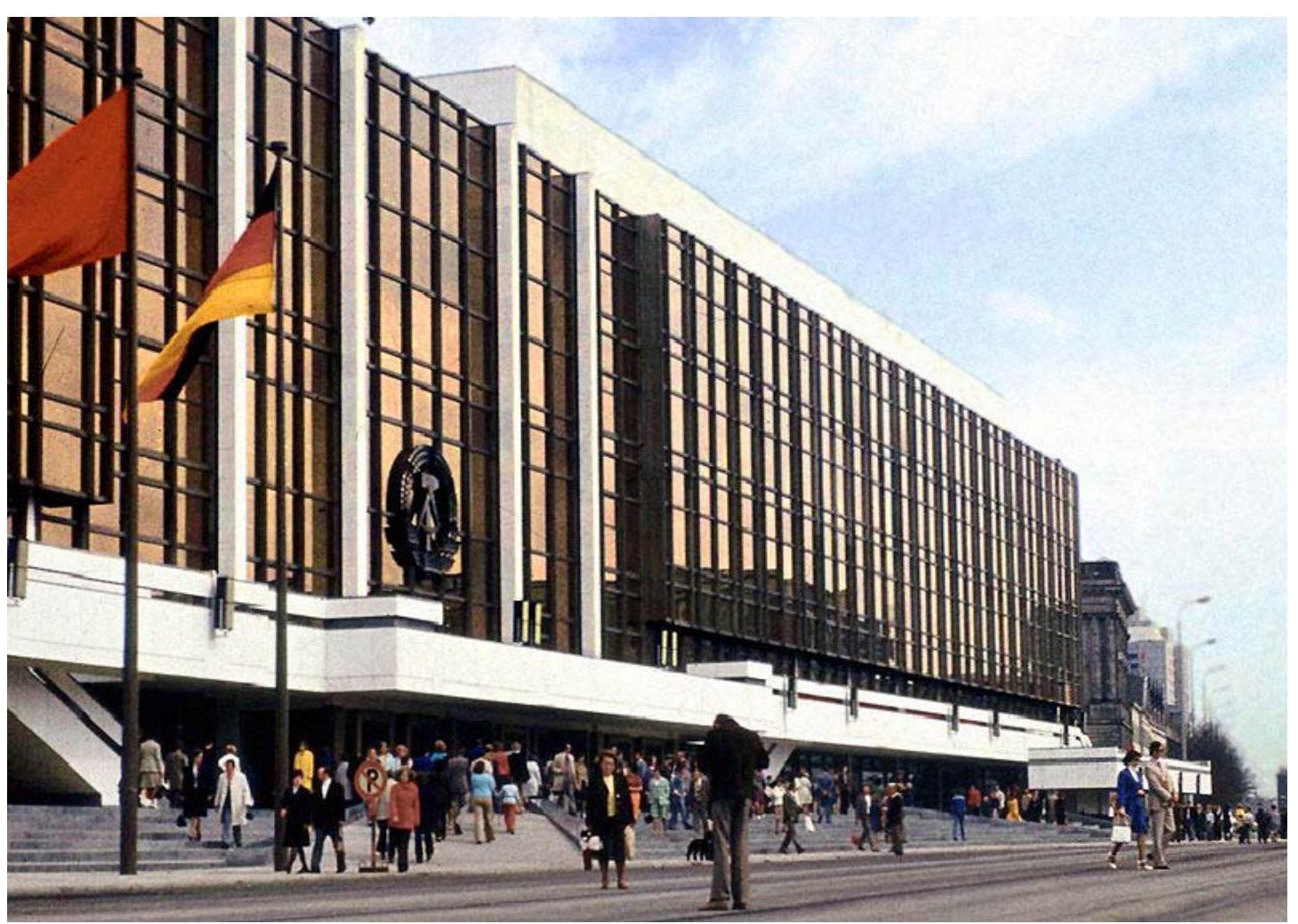

Figure 8. The Palast der Republik, 1980s. Photo: Lutz Schramm

(http://de.wikipedia.org/w/index.php?title=Datei:Palast_der_Republik_Berlin_DDR.jpg\&filetimestamp=2 0080211205921). Creative Commons.

In addition to the question of what to do with various sites tainted by association with the National Socialist regime, there was the issue of if, and how, the city should physically mark its Jewish history and the Holocaust. The idea of a Jewish museum was raised in the 1980s and became the subject of an architectural competition in 1989.

However, construction of Libeskind's winning design was delayed by various controversies, and the building was only completed in 1999 (figure 9). The architect specifically foregrounded the notion of the 'void' in his design: empty space was incorporated so as to 'draw attention to the vacuum in Berlin left by the disappearance of tens of thousands of its Jews' (Large 2000: 636). This design stood to 'articulate memory and our relationship to it in its very spatial organization,' as Huyssen puts it (1997: 75). The possibility of a Holocaust memorial was also raised in the 1980s and it, too, was a live issue throughout the 1990s, although its design was only settled in 1999, and construction completed in 2005, well after Siegert’s Berlin Babylon was shot. ${ }^{6}$

\footnotetext{
${ }^{6}$ A design by the US architect Peter Eisenman was settled upon in 1999, after an exhaustive but unconcluded/unconcludable debate, which related, inter alia to the 'dilemma of commemoration', that is to how to weigh up the imperatives for aesthetic and cognitive commemoration (Christhard Hoffmann
} 


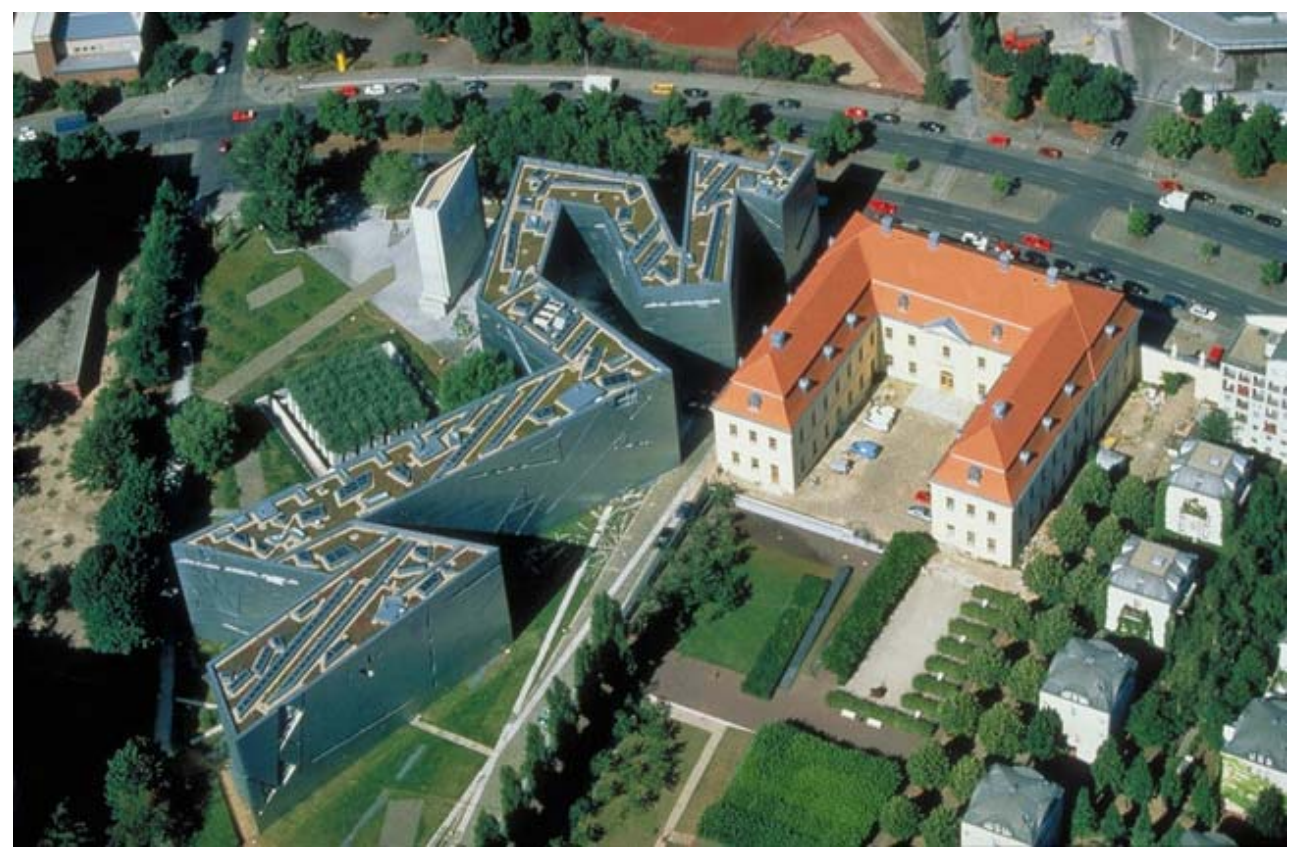

Figure 9. The Jewish Museum, Berlin. Photo: Studio Daniel Libeskind (1999)

(http://de.wikipedia.org/w/index.php?title=Datei:JewishMuseumBerlinAerial.jpg\&filetimestamp=200807 23023831). Creative Commons.

\section{Hubertus Siegert: City and film as open text}

Siegert (born in 1959 in Düsseldorf ${ }^{7}$ ) is an autodidact filmmaker. He is also one for whom film music is extremely important, especially given that it is able to engage the audience on an additional, non-visual level. ${ }^{8}$ Siegert moved to West-Berlin in 1980, where he studied history, art history and theatre, as well as landscape planning. He first conceived of Berlin Babylon in the early 1990s, when he was struck by the sense of openness and transition attaching to Berlin's physical character, and particularly to the district of Mitte, which was a central location in the city, but which very much bore the scars of the recent past. His feelings were quite ambivalent and certainly accommodated an appreciation for what Hoffmann-Axthelm called 'beauty in the form of destruction' (quoted in Ledanff 2003: 53). To his eyes, the city was 'broken in many respects, but [it] was unique and had the beauty of the incomplete and the unfinished. It was in this

quoted in Ledanff 2003: 39). The 'Memorial to the Murdered Jews of Europe' (completed in 2005) is built on a large site to the south of the Brandenburg Gate. It is a field of 2700 stone pillars of varying heights, which engenders in the individual a sense of disorientation. The site of the future memorial does feature briefly in Berlin Babylon, shortly before we see footage of the Jewish Museum. See the special edition of German Politics \& Society (1999) and Neill (2005) for a summary of the debates about the Memorial.

${ }^{7}$ Siegert's heritage as a Düsseldorfer is not without significance. That city had been subjected to its own unprecedented urban rebuilding program since the 1960s, at precisely when Siegert was growing up.

${ }^{8}$ Biographical information was provided by Hubertus Siegert in a telephone interview with the author on 6 November 2009. Future references to this interview will take the form: (Siegert 2009). 
very emptiness that everything seemed open, and [so] much possible' (Siegert 2001; my trans). It was that sense of openness that Siegert initially wished to document (Siegert 2001).

However, his project developed into a study of the Bauwut (building fury) that descended over Berlin after its status as future capital was settled, and the policy of ‘critical reconstruction’ was decided upon (Siegert 2001). The filmmaker now set about observing the players in the 'Babylonian' redevelopment of Berlin - the tale of the Tower of Babel is included as an epigraph at the beginning of the film and gives it its basic orientation — as well as gently exposing the hierarchy of power and interests involved in (re)development. ${ }^{9}$ His new concept was also to explore: 'just how much ... architects and politicians are really aware of what they are doing ... I felt that there was no, or not enough reflection on this question [of how to handle the lost past] among architects and those who would rebuild Berlin' (quoted in Stern 2002: 127-128). Siegert's project is therefore also about history itself, as his inclusion in the film of a passage from Walter Benjamin’s 1940 'On the Concept of History’ further reinforces. The extract refers to the 'Angel of History':

The Angel of History

His Countenance faces the past

Where we can see a chain of events he sees a single catastrophe.

Rubble piles up relentlessly.

Layers of it are hurled at his feet.

He longs to linger,

To wake the dead and reconstruct the rubble.

But a storm has brewed in paradise.

The tempest has unfurled its wings

It is so strong he cannot lower them again.

The storm drives him pell-mell into the future.

He turns his back on what's to come.

Meanwhile the pile of rubble grows sky high before his eyes.

The phenomenon that we call progress is this mighty storm. (Benjamin 1940, quoted in Neill 2005: 339)

Siegert, the erstwhile history student, operating in the spirit of Benjamin’s lines, complicates the notion of 'history' as it was commonly applied in the debate about Berlin’s renewal, where twentieth century history was often neglected in favour of reinstalling an earlier image of $19^{\text {th }}$ century Berlin. His is not an inherently

\footnotetext{
${ }^{9}$ This focus reflects the essential point made by Jacobs in 1993 that '[p]lanning controversies are discursive battles in which certain interests, reliant upon or loyal to specific discourses, have different political leverage within a discursive field predisposed to arguments of architectural aesthetics' (quoted in Colomb 2007: 297).
} 
'preservationist' attitude — although this term is of limited use in such a layered city as Berlin: which historical layer of the city ought to be preserved? At the expense of what other layer? ${ }^{10}$ Indeed, Siegert adheres to the possibility and inevitability of change; his starting point is simply that the new building which replaces the old must be an improvement on the old, and that this question should not be approached in too reductive (or functionalist-aestheticist) a fashion. For, following a Panofsky-inspired approach, ${ }^{11}$ a building is not just an aesthetic object or form, it is also the accretion of memory/its history:

The starting point [in the philosophy of critical reconstruction] was firstly that a functionally better state is always the correct one, and, secondly, that the historically earlier form of the city needed to be reconstructed. It was all about the idea of completing the new city. Each and every building which can measure up to some lowest common denominator of 'beautiful' and 'historic' is renovated to the point where the last remnant of memory is polished from the stone. Everything that is scraggy, grey or ugly — qualities which can certainly have gravitas and dignity — gets torn down, built upon or destroyed, until the city can no longer function as a repository of memory. (Siegert 2001) $)^{12}$

Despite his strong underlying views, Siegert’s intention with Berlin Babylon was nevertheless primarily a documentary one, in which he used contrast as his central organising principle in order to sustain an interesting, yet dramaturgically open texture (Siegert 2001). Siegert expressly wished to present a range of perspectives, and to avoid from labouring any particular opinion: 'it was important to us with the montage [of the footage] that we did not illustrate any [particular] opinion, but rather that we combined a multitude of perspectives' (Siegert 2001). It was vital that the film had a texture capable of engendering active interpretation by an audience member:

If a scene were to be obvious in terms of a statement, then, what with my mode of observation, it would become dead and abstract .... If anyone is looking to have his or her own critical attitude verbalised, then those expectations will not be accommodated. However, the contrasting perspectives allow everyone to develop his or her own perspective. (Siegert 2001)

In other words, Siegert hoped that his film would spur its viewers to ask questions about the redevelopment of Berlin, and beyond that about German history. The way in which music and sound is employed in the film is also consistent with this aim.

\footnotetext{
${ }^{10}$ Susanne Ledanff points out that the debates about Berlin raised 'conflicting preservationist ideas' (2003: 38).

${ }^{11}$ Siegert has confirmed the influence that the art historian Erwin Panofsky has had on him (Siegert 2009). Panofsky is perhaps best known for his development of Aby Warburg's notion of iconology, in which the deep levels of intrinsic meaning or content in a given artwork, rather than its form, are explored. See, for example, Panofsky (1939).

12 Translations from Siegert are mine.
} 


\section{Music and history}

The use of historical music in Berlin Babylon, a film concerned with the past (and with the obscuring thereof) ought not surprise. Nor should the form in which the citations occasionally take place; or the way in which the historical material is sometimes commented upon by other parts of the soundtrack. Just as Berlin Babylon contains archival footage (of the bombing of the city at the end of World War II and of ruined buildings being dynamited in the late 1940s and 1950s), its soundtrack features music from earlier eras, composed by Beethoven, Wagner, and Brahms, as well as by Hanns Eisler. However, apart from a short extract from the overture of Wagner's Götterdämmerung — suitably alienated by the addition of threatening, diegetic helicopter noise, recorded whilst the accompanying aerial footage was taken, but also included as an intertextual reference to Apocalypse Now (1979)—only one such piece is included on the commercially released soundtrack; a rather scratchy 78 recording of Beethoven's Trauermarsch (funeral march) from his $3^{\text {rd }}$ Symphony, Eroica. I focus on that piece here. $^{13}$

Roger Hillman has shown that in German art film since the 1960s the incorporation of music from the classical tradition contributes an extra dimension in which the film text can be read. Classical music, or at least certain pieces of it, has often accreted a thick range of associations, such that German film audiences will typically be able to read that range of associations in conjunction with, or indeed against, the visual dimension of the film. In the New German Cinema in particular, filmmakers were adept at playing those two aspects off against each other in highly productive ways (Hillman 2005). Like the old buildings that we see being demolished in Berlin Babylon, Beethoven’s multivalent music especially has history accreted to it. It had, along with Wagner’s

\footnotetext{
${ }^{13}$ I note, however, that all of the pieces of classical music used in the film are highly significant. The Berlin-based musician Thomas Krinzinger acted as adviser to Siegert here. The extract from Brahms's Deutsches Requiem - 'Selig sind, die da Leid tragen' (Blessed are those who mourn)—is, like Beethoven's Trauermarsch, melancholic and funereal, and was consonant with Siegert's intention to introduce a sobering note into the popular celebration of Berlin's reconstruction. The extracts from Wagner's Götterdämmerung (Trauermarsch and Walküre Vorspiel) are multiply coded. Wagner's associations with National Socialism (his anti-Semitism, and Hitler's proximity to the Bayreuth circle) are notorious. Nevertheless, as Siegert points out, Wagner's hero, Siegfried, is the master of his own downfall. The filmmaker intended to use this association to suggest that the destruction of the Stadtschloss, which is shown in the film via archival footage accompanied by one of the Wagner extracts, was Germany's own fault. In another aerial shot of the Karl-Marx-Allee, Siegert opts for Hanns Eisler's and Johannes R. Becher's national anthem of the GDR. The anthem specifically refers to the way in which the East German state has 'risen from ruins'; its quoting after the demise of the East German state is not without irony, yet it lends a gravitas to the footage of the still impressive Karl-Marx-Allee. Thanks to Hubertus Siegert for pointing out some of these resonances (Siegert 2009).
} 
music, been a favourite of the National Socialists (but of course not only of them). ${ }^{14}$ Contrastingly, the Ode to Joy from his $9^{\text {th }}$ Symphony was also performed on the eve of reunification. The form in which the Trauermarsch is quoted in Berlin Babylon, the way in which it mutates at the end of the track, and the way in which it is combined with the film's visual images are quite significant. The historical 78 selected for the soundtrack was recorded in Berlin, under the conductor Hans Knappertsbusch, in 1934, in the year after Hitler's ascension to power. However the piece does not stand on its own, as an uncommented-upon citation of a previous era. Knappertsbusch's Trauermarsch segues violently into the sound, first of rubble, then of smashing glass. At the same time, the visual track cuts from archival footage of the opening of the Brandenburg Gate in November 1989-where the sombre tone of the Trauermarsch and the gloomy weather counterpoint the jubilation usually associated with images of the fall of the Wall; perhaps even as a reminder not to forget the reasons for Germany’s division- to shots of segments of the Wall being disposed of, and then to a collapsing 'DDR Moderne' building as it shears in slow motion across the screen, its windows shattering one by one.

This smashing glass sound, I would argue, is multiply coded. Not only is it diegetic, but smashed glass is also historically resonant in Germany, especially when heard in association with a recording from the 1930s. As is well known, on the night of 9 November 1938 the so-called Reichskristallnacht (Night of the Broken Glass) occurred, when violence was perpetrated against Jewish lives and property. This event-occurring 51 years, to the day, before the opening of the Wall, which the film has just depictedis obliquely referenced by the 1934 Trauermarsch and its brutalised ending. Just as the 1930s proceeded towards the Reichskristallnacht, and barbarism emerged from German culture, Knappertsbusch's historical recording metamorphoses into breaking glass. This aspect of the soundtrack aptly portrays the discontinuities and ruptures in twentieth century German history, as does the way in which silence is employed in the film. ${ }^{15}$

\footnotetext{
${ }^{14}$ Large reports that the $9^{\text {th }}$ symphony had been used, for example, at Hitler's public birthday celebrations in April 1942 (2001: 590). On the fate of classical music under National Socialism, see, for example, Kater (1997).

${ }^{15}$ It should be noted, however, that Siegert had not specifically intended the Knappertsbusch recording and its ending to reference the so-called Reichskristallnacht. He had primarily wished to use the music and its sombre tone to counter the jubilation generally associated with the fall of the Wall. The selection of an historical recording was based on the fact that no licensing fee needed to be paid. Siegert has noted, however, that associations with the Reichskristallnacht may well be made by audience members aware of German history (Siegert 2009).
} 


\section{Silence as aural 'void'}

As we have seen, the idea that Berlin was a city with voids was important in the 1990s. Whilst, for the most part, the proponents of redevelopment had seen voids as an opportunity, or even a mandate to rebuild, others like Libeskind argued that they should be retained, in part because voids can engender memory and the retention of moralhistorical discourse (Huyssen 1997). A void can be an empowering thing for the (historical) imagination, as Siegert also recognised early in the 1990s.

Berlin Babylon's DVD soundtrack employs silence as acoustical void in a similar fashion to the way in which Libeskind conceived of the void in the Jewish Museum. ${ }^{16}$ Here the soundtrack is in keeping with, rather than contrapuntal to, the footage. Footage of the empty site of the future Holocaust Memorial and then of the just completed, but still empty Jewish Museum is shown, accompanied by a silent soundtrack (although increasingly, a ghostly "rushing" sound may be discerned as the footage progresses). This strategic use of silence, which in conjunction with the portrayal of Libeskind's 'void' draws attention to absences in German culture, is heightened by the high profile of sound elsewhere in the soundtrack. The immediately preceding scene is a crescendo of menacing clouds passing overhead, speeding up all the while, as Walter Benjamin's passage on the 'Angel of History' is recited against an increasingly loud and tempestuous storm-soundscape. It abruptly cuts to silence and to footage of the void. This strategic use of silence is also consistent with Einstürzende Neubauten's musical practices in recent years, especially on the 2000 album Silence is Sexy, which sought to provoke the musical imagination not so much by noise, as had been the case in the past, but by silence and its juxtaposition against sound (see Borchardt 2003: 118).

\section{'What is the lay of the land?’: Einstürzende Neubauten’s film music}

If there were a band perfectly qualified to provide a soundtrack for a film that thematises Berlin, demolition and architecture, then it would have to be Einstürzende Neubauten, the Berlin group based around the singer Blixa Bargeld (born, like Siegert, in 1959). Indeed, one could almost imagine the film being tailor-made as a vehicle for

\footnotetext{
${ }^{16}$ This is a point also made by Neill (2005: 344). It should be observed that the cinema version of Berlin Babylon does not contain silence at this point. Instead, it features Luigi Nono's 1955/56 composition Il Canto Sospeso, itself conceived as a commemoration of the victims of fascism. It was too expensive to license this recording for the DVD, and for this reason silence was used. Siegert noted, however, that this was also an appropriate way of sonically representing the gap in Berlin caused by the Holocaust (Siegert 2009).
} 
the band. ${ }^{17}$ From the beginning, the band has had a focus on architecture and the built environment, which was partly a result of the alternative squatters' milieu, in which several members of the band were involved in the early 1980s, and where there was a highly politicised sense of reclaiming disused buildings and opposing development. ${ }^{18}$ In line with this tradition, the band not only 'reclaimed' junk objects and noise as potential sources of music, it also made a point out of performing in a series of significant, disused spaces. Sometimes these spaces were selected to draw attention to the surrounding (post-)industrial environment. (An early concert took place in a steel roadway underpass, for example). On other occasions, historically burdened sites were used. In 1986, for example, the group performed in the disused 'Golden Chamber' at the Nuremberg parade ground, in a provocative 'exorcism' supposed to be an 'objection to Hitler’s words in stone’ (Borchardt 2003: 38. My translation).

Textually, the group has also long engaged with architecture, and with buildings, old and new. The most obvious textual reference is the band's name itself, 'Collapsing New Buildings,' a seeming contradiction in terms, which can nevertheless be associated with the squatters' anti-development philosophy. ${ }^{19}$ The titles of various pieces have also taken a critical, if not always un-cryptic, stance towards architecture. This is evident, not only in the group’s long-running series of compilations, 'Strategies against Architecture,' but also in the notion that Architektur ist Geiselnahme (Architecture is the taking of hostages), first referred to in 1981, and then picked up again for the Berlin Babylon soundtrack (see below).

Of the band's music on the soundtrack, there are only two songs ('Architektur ist Geiselnahme' and 'Die Befindlichkeit des Landes,' which will be examined below); otherwise it is instrumental. That instrumental music has several important characteristics, which make their own comment on the project of the Berlin Republic. Firstly, there is the manner in which noise is employed. One is often never quite sure where the line between diegetic noise (inter alia from the loud building sites depicted)

\footnotetext{
${ }^{17}$ In fact, the band had already recorded, prior to its involvement in the film, 'Was ist die Befindlichkeit des Landes' ('What is the lay of the land'), a song that reflects on the redevelopment of Berlin (see below).

${ }^{18}$ On the squatters' movement, see for example, Large (2001: 492-495). On the history of the band, and on their early links with the squatters' movement, see Borchardt (2003) and Dax and Defcon (2006).

${ }^{19}$ The contradiction of a collapsing new building was soon put into question, however; some months after the group selected its name, the roof of the newly built Berliner Kongresshalle collapsed, giving that name a special piquancy.
} 
and non-diegetic soundtrack music can be drawn, which is partly also a function of the sound engineer Alexander Saal's montage skill. As with Einstürzende Neubauten's broader oeuvre and its use of noise, this encourages us to consider our preconceptions about what music and noise are, and about aesthetics more generally. This thrust is quite complementary with Siegert's points, made in interview, about the 'beauty' of disrepair and discontinuity in Berlin's immediate post-Wall cityscape.

Secondly, the pace of Einstürzende Neubauten's music is noteworthy. It is often quite slow, and this keys in especially with several of the film's early accompanying sequences_-of largely empty city streets around Mitte-which were shot in slow motion. There is room in this 'slow' aesthetic for contemplation, which is in stark contrast with the pace of Berlin's re-development during what Siegert calls a 'hurried decade,' where pace seemed to exclude contemplation (Siegert 2001). In fact, Siegert conceived of his film as an attempt 'to slow down this overly quick epoch' (DVD cover notes. My translation), and Einstürzende Neubauten's music generally contributes to that slowing down. This is not to say that pace has been excluded from the film; indeed certain scenes have been sped up. Speed is associated, not only with the tumultuous 'Angel of History' scene, for example, but also with time-lapse footage of the opening of the glitzy Potsdamer Platz, which exemplified the superficial direction in which the Berlin Republic seemed so speedily to be heading. ${ }^{20}$

Finally, Einstürzende Neubauten's instrumental music allows itself a wry comment on some of the 'star' architects, including Helmut Jahn, designer of the Potsdamer Platz's Sony Centre (figure 10). While the filmmaker did not express any particular opinion of Berlin's redevelopment (at least in relation to the visuals), the recurring use of a subtle but rather sinister and menacing musical motif_-an alienated triangle sound —in some of the scenes featuring Jahn and others evokes a distinct feeling of unease about the high profile developments. Perhaps that musical choice guided audience members to think about potential 'villains' in the story. I would suggest it certainly contributed to what one critic called the film's 'thriller-format' (Berliner Zeitung 2001). The sense of unease evoked here is also compounded by the generally melancholic tenor of Einstürzende Neubauten's music, and by the lyrics of its two songs.

\footnotetext{
${ }^{20}$ The music accompanying this sped-up footage_-included in an ironic, if not downright humorous quotation-is the upbeat Rondo-Allegro from Beethoven's Piano Concerto No. 1 in C Opus 15.
} 


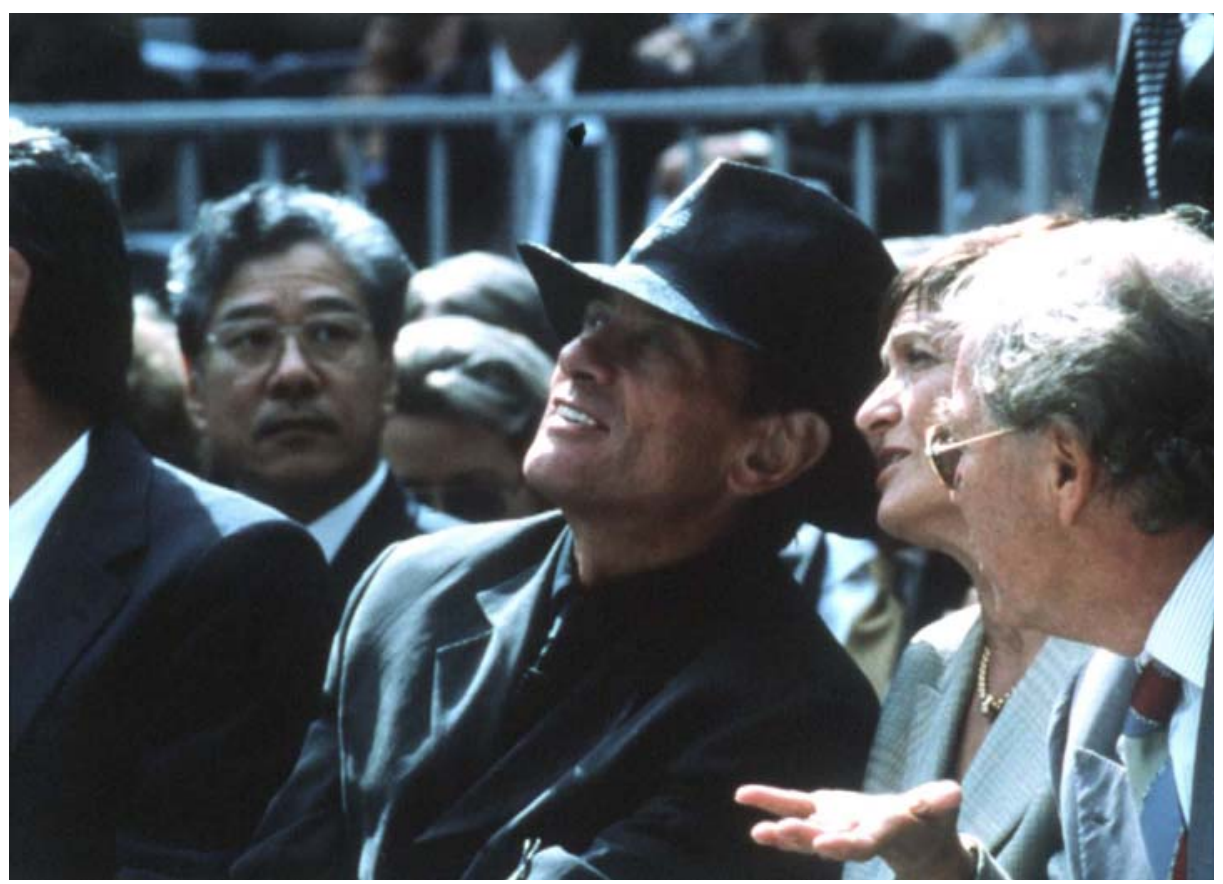

Figure 10. Helmut Jahn; still from Berlin Babylon.

(www.berlinbabylon.de/Media.Sumo/bbjahn.jpg). Image courtesy of Hubertus Siegert/ S.U.M.O. Film.

The song 'Architektur ist Geiselnahme’ contains a series of critical yet somewhat cryptic textual fragments on architecture and development. Apart from the title’s notion of architecture as the 'taking of hostages,' it refers to 'building fury,' to

Fassadenschwindel (façade-dizzyness/façade-fraud) and 'façade-liars,' as well as to the idea of 'a plumb-bob as the protractor [or measure] of history' (my translations). On its own terms, the song's emphasis on facades might be interpreted as a comment on the redevelopment of the Potsdamer Platz, with its prominent glass curtain-wall buildings. However, whilst we see some footage of building sites over the course of the song, it is mainly disused old buildings devoid of human life that we see, and the song-at least as it has been employed by Siegert—-seems therefore to be commenting on previous eras of development, or development in general, rather than the 1990s phase of Bauwut in particular. For Siegert, the song's title notion conveys a sense of the 'tragedy of modernity' whereby the individual is overwhelmed by the sheer scale of modernity and late capitalism, just as some of the individual workers in the film, such as those working at the building site of the new Hauptbahnhof are dwarved, 'taken hostage' even, by the massive machines and constructions at which they labour. That there is a link between the 'tragedy of modernity' and the 'tragedy of German history' is established by the way in which the footage of the Hauptbahnhof construction is quickly followed by 
sombre black and white footage of the opening of the renovated Reichstag building, another historically ‘burdened’ structure (Siegert 2009).

The second song, which is heard during the closing credits, actually predates the film. Unlike ‘Architektur is Geiselnahme,' 'Die Befindlichkeit des Landes' (2000) does relate specifically to the 1990s Bauwut, and expressly references the Potsdamer Platz redevelopment. ${ }^{21}$ Einstürzende Neubauten had been associated with an alternative (West) Berlin scene which was, by the 1990s, being marginalized along with the 'historical aura' of the Cold War era city. As Bargeld recently noted, 'the city in which I grew up and with which I and the Neubauten were associated is no longer there. It simply no longer exists' (quoted in Dax \& Defcon 2006: 249. My translation). Under the circumstances, Bargeld held critical views towards the redevelopment of his hometown, and once even said that he 'would like to tear down the Stadtschloss again, before it has even been erected’ (quoted in Dax \& Defcon 2006: 246. My translation). However, 'Die Befindlichkeit' is not a protest song, even though it did hold that character when first conceived. From Bargeld's perspective, the song only shed that mantle-with which he was never comfortable - when he introduced the textual motif of melancholia (Borchardt 2003: 117-118). His song marks the passing of the 'scarfaced terrain' of the old city, and the construction of the new. However, it does so with melancholia, an affect which Bargeld now transfers onto the whole of Germany (this is the answer to his rhetorical question 'What is the lay of the land?'). He suggests that despite the speed of construction in the Berlin Republic, the past refuses to go away (war-time bunkers still exist; the 'traitor' Marlene Dietrich is still unwelcome ${ }^{22}$ ). The new buildings are, despite their appearance, actually no more than 'future ruins.' As Siegert would do in his film, Bargeld also incorporated into his text the figure of Benjamin’s 'Angel of History,' suggesting that (s)he continues to watch these frenetic developments with concern.

\footnotetext{
${ }^{21}$ The reference in the lyrics to the red 'Info-Box' is to a display pavilion that was erected at the Potsdamer Platz prior to construction on the site. Citizens could climb into the 'Info-Box' and view a range of materials illustrating the proposed re-development.

${ }^{22}$ In 1930, the Berlin-born Dietrich emigrated to the USA. Convinced that she should take an active role against the National Socialist regime, she gave numerous wartime concerts for American GIs stationed in Europe and North Africa. This earned her opprobrium in some quarters of postwar Germany as a Vaterlandsverraeterin (traitor to the father land). Even after her death in 1992, some isolated voices still regarded her in this light and the decision of the Berlin Senate in 1996-1997 to name a street and then a prominent square (the Marlene-Dietrich-Platz, adjacent to the Potsdamer Platz) after her, met with controversy.
} 
By recourse to the notion of melancholia, Bargeld's text retreats from the polemic of a naïve protest song (just as Siegert's refusal to use a voiceover eschews polemics). It thereby makes the song's critique slightly more oblique, and demanding of interpretation on the part of the listener. What exactly was the cause of the melancholia of which Bargeld sang? How should it be weighted? The notion of melancholia has, of course, a long history in the German-speaking context. In Freud's 'Mourning and Melancholia' (1917), for example, he theorised that, in contradistinction to transitory grief, the melancholic was unable to grieve the passing of a love object, and come to terms with it, because he or she identified so strongly with that object. This notion was then applied by Alexander and Margarete Mitscherlich, in their 1967 work The Inability to Mourn, to postwar German society. The melancholia they diagnosed in their patients related to a strong attachment to the figure of Hitler, whose passing they were socially prevented from mourning. Whilst Bargeld retains in his song the notion of a German past that, notwithstanding the city's superficial face-lift, will not and cannot disappear, he is personally more positive about the creative processes which a state of melancholia might allow (Schlüter 2000). Siegert, who himself has spoken of a sense of having an 'geerbte Trauer' (inherited mourning) in relation to the German past, similarly recognises a value in melancholia, which could be brought to bear against the misplaced mainstream enthusiasm — if not downright euphoria — for a new Germany in the wake of unification (Siegert 2009). This explains his motivation for using generally sombre, melancholic music in Berlin Babylon.

\section{Coda and conclusion}

Three years after Berlin Babylon was completed, Einstürzende Neubauten performed live in the (then) still standing Palast der Republik. This was in keeping with the band's tradition of performing in historically significant disused spaces, as well as with Bargeld's opposition to the Palast's designated successor, a replica Stadtschloss. It was also part of the Volkspalast (people's palace) initiative that sought to make interim use of the Palast in a manner counter to the dominant trend towards the commercialisation of culture and leisure, which has become part of the Berlin Republic's agenda (Ledanff 2003: 62-63; Colomb 2007: 305). Instead of commenting on the project of the Berlin Republic, as had been the case in their soundtrack to Siegert's film, the band was now practically and subversively involved in re-imagining and re-functionalising one of the city's historically burdened buildings, on the eve of its destruction. 
Twenty years after the fall of the Wall, the phase of Berlin's rapid re-development is over; the battles over the most difficult buildings and sites seem to have been had (even if some sites designated for development are still fallow, and the question of where the funds for reconstructing the Stadtschloss will come from remains open). The notion of maintaining the physical scars of Berlin has largely retreated from the mainstream discourse. ${ }^{23}$ Siegert's film stands as a worthy monument to the initial post-Wall phase, and to the moral issues relating to the collapse of buildings and of history, in the anxious drive to fill the voids. Yet it does not make its points in a cudgel-like fashion. The audience is not presented with fully formed arguments that would remove from it the obligation to engage in active interpretation. Whilst the film's visual montage expressly avoids labouring an opinion, its soundtrack contains various suggestive cues for thought (in silence, historical quotation, melancholic tenor and lyrics) which are occasionally more explicit than the visuals—and which give the film a 'moral kick' (Siegert 2009) — but which still contain space for and mandate the creative imagination, and an engagement with recent German history.

\section{Acknowledgements}

I would like to thank Hubertus Siegert and Boris Wilsdorf for agreeing to be interviewed for this article, and S.U.M.O. Film for permission to use stills from Berlin Babylon. This article results from an ARCfunded research project.

\section{Reference List}

Augstein, R., et al (eds.) 1987, 'Historikerstreit.’ Die Dokumentation der Konstroverse um die Einzigartigkeit der nationalsozialistischen Judenvernichtung. Piper, Munich.

Berliner Zeitung. Review of Berlin Babylon, precise date and page number not known, quoted on the DVD cover of the film.

Borchardt, K. 2003, Einstürzende Neubauten. Hannibal, Höfen.

Colomb, C. 2007, 'Requiem for a Lost Palast. "Revanchist Urban Planning” and "Burdened Landscapes" of the German Democratic Republic in the New Berlin,’ Planning Perspectives, vol. 22 (July), 283-323.

Cooke, P. 2005, Representing East Germany Since Unification: From Colonization to Nostalgia. Berg, Oxford.

Dax, M. \& Defcon, R.T. (eds.) 2006, Nur was nicht ist, ist möglich: die Geschichte der Einstürzenden Neubauten._Bosworth, Berlin.

Einstürzende Neubauten 2000, Silence is Sexy. Zomba Records/Rough Trade. 2001, Berlin Babylon (Original Soundtrack). Grand Harbor.

Freud, S. 2005 [1917], 'Mourning and Melancholia,' in The Future of an Illusion, (ed.) S. Freud, trans. S. Whiteside, Penguin, London.

\footnotetext{
${ }^{23}$ Ledanff observes that by the time the vote was taken in 2002 to demolish the Palast der Republik, the 'old arguments of Berlin as a city of dissonances, the cult of wounds in the fabric of the city, were briefly raised in the Bundestag debate and swept aside' (2003: 60).
} 
German Politics \& Society, special issue, vol. 17, no. 3 (Fall 1999).

Hillman, R. 2005, Unsettling Scores: German Film, Music and Ideology. Indiana University Press, Bloomington.

Huyssen, A. 1997, 'The Voids of Berlin,' Critical Inquiry, vol. 24, no. 1, 57-81.

Kater, M. 1997, The Twisted Muse: Musicians and Their Music in the Third Reich. Oxford University Press, New York.

Large, D.C. 2001, Berlin. Allen Lane, London.

Ledanff, S. 2003, 'The Palace of the Republic Versus the Stadtschloss: The Dilemmas of Planning in the Heart of Berlin,' German Politics and Society, vol. 21, no. 4, 30-73.

Mitscherlich, A. \& Mitscherlich, M. 1975 [1967], The Inability to Mourn: Principles of Collective Behavior. Trans B. R. Placzek. Grove Press, New York.

Neill, W.J.V. 2005, 'Berlin Babylon: The Spatiality of Memory and Identity in Recent Planning for the German Capital,’ Planning Theory and Practice, vol. 6, no.3, 335-53.

Ockman, J. (ed.) 2002, Out of Ground Zero: Case Studies in Urban Reinvention. Prestel, Munich et al.

Panofsky, E. 1939, Studies in Iconology: Humanistic Themes in the Art of the Renaissance. Oxford University Press, New York.

Schlüter, C. 2000, ‘Als Ruine vollendet. 20 Jahre Einstürzende Neubauten: Ein Gespräch mit Blixa Bargeld,’ Die Zeit. April 20. Online, available: http://www.zeit.de/2000/17/Als_Ruine_vollendet [Accessed 18 September 2009].

Siegert, H. 2009, Telephone Interview with Andrew W. Hurley. Nov. 6. (dir.) 2001a, Berlin Babylon. Absolut Medien.

2001b, ‘Blickwinkel,' Online, available: http://www.berlinbabylon.de/Pages/berlinbabylon2.html [Accessed 18 September 2009].

Siegert, H. \& Stern, R. 2002, ‘A Discussion of Berlin Babylon,' in Out of Ground Zero: Case Studies in Urban Reinvention. (ed.) J. Ockman. Prestel, Munich et al. 126-31.

Stern, R. 2002, 'Berlin: Film and the Representation of Urban Reconstruction Since the Fall of the Wall' [Introduction], in Out of Ground Zero, (ed.) J. Ockman, 117-24.

Taberner, S. 2005, German Literature of the 1990s and Beyond: Normalization and the Berlin Republic. Camden House, Rochester, NY.

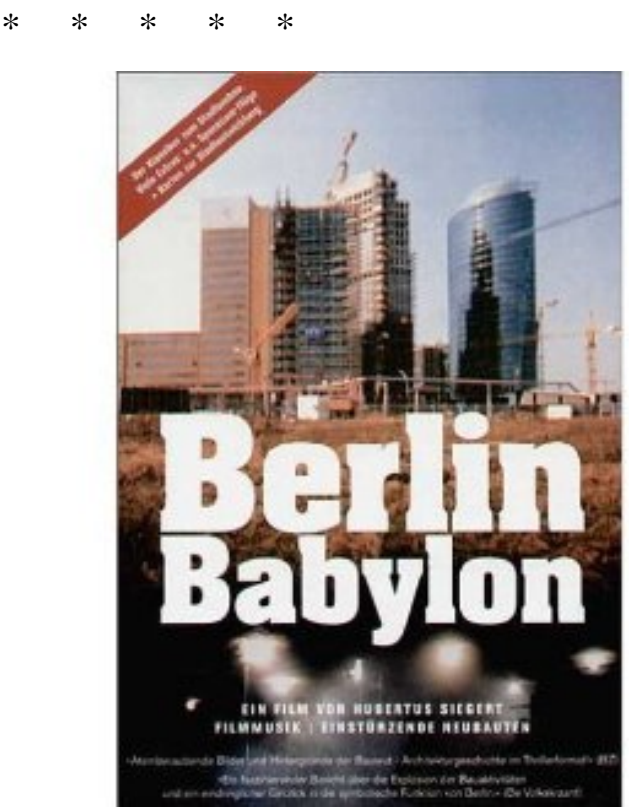

Original Berlin Babylon DVD available (region: codefree). Please contact: ET@sumofilm.de 